\title{
Organization and Implementation of the teaching of Computer Basic Course "Classification+Grading" in Local Comprehensive Universities
}

\author{
Hongxi Jiang, Jianjun Cheng, Gejing Xu \\ Hubei University of Arts and Science, Xiangyang, Hubei, 441053, China
}

Keywords: Computer basic teaching, Teaching reform, Classification teaching, Graded teaching

\begin{abstract}
There are many discipline categories in local comprehensive universities and the students are widespread. Computer skill and professional differences of the freshmen bring challenges to the setting and teaching organization of public computer course. On the basis of analyzing the setting and teaching situation of computer basic course in our university, this paper puts forward the teaching mode of the course classification setting and grading organization teaching, and has achieved a good teaching effect.
\end{abstract}

\section{Teaching situation of computer basic courses in our school.}

Over the years, the setting of the public computer courses of Hu Bei University of Arts and Science (formerly named Xiangfan College) was basically in accordance with the principle guidance the "The steering committee of the teaching of computer basic courses in the higher education department of the Ministry of Education" (the following is short as the teaching steering commission) proposed. Two levels of courses are offered to all non computer majors at present: computer foundations and program design basis. Other courses recommended by the teaching steering commission are set up according to the need of all kinds of specialty.

In recent years, we have carried out a series of reforms in the teaching of computer basic courses. For the computer basic courses, our main approaches are: 1 . taking into account the strong operability of the course, all the class hours are arranged in the laboratory; 2. distinguishing theory from experiment teaching hours and teaching contents are divided according to the knowledge points, the "talking while practicing, talking and practicing" teaching methods is adopted; 3. On handling the teaching contents, we give full consideration to the training goal of various different professional talents and the different requirements to the computer application ability, we are targeted to revise the curriculum teaching syllabus and examination syllabus divided into engineering, art and sports, literature and history respectively.

In order to better carry out targeted teaching, we used a hierarchical teaching approach for the "computer basis" course combined with the setting situation of computer basic laboratory and the reality of school teaching, which has achieved a good teaching effect.

\section{The organization and implementation of computer basic classification and grading teaching in our university}

Classification of students. According to the differences of discipline categories and specialty, the school sets up 14 secondary colleges which contain music college, academy of fine arts. We analyze and sum up the teaching situation of public computer course for many years, and put forward that all the students in the whole school should be divided into three categories which contain the great science and engineering (the following is short as Class A), the great liberal arts (the following is short as Class B), and the music sports arts (the following is short as Class C) to set up public computer course respectively. Specialty of class A contains educational professions such as the conventional science and engineering and technical education, of which the public computer courses open the "computer basis -A" (the amount of class hour is 18 class hours' theory +18 class hours' experiment) and the "program design basis (C language)" (the amount of class hour is 36 class hours' theory +18 class hours' experiment); Specialty of class B refers to all the majors without major of music, sports, arts and all the majors of class A, of which the public computer courses open the 
"computer basis -B" (the amount of class hour is 18 class hours' theory +18 class hours' experiment) and " program design basis (Access)" (the amount of class hour is 36 class hours' theory +18 class hours' experiment). Class $\mathrm{C}$ refers to the corresponding majors contained in the college of music, academy of fine arts, institute of physical education, of which the public computer courses only set up a "computer basis -C" the amount of class hour is 28 class hours' theory + 36 class hours' experiment) without "the program design basis".

Grading of students. For every class of students, in the specific organization of the implementation of the "computer basis" curriculum teaching, we take the grading of teaching methods, that is, grading based on classification. Specific practices are as follows:

First, we drew up the teaching implementation plan "computer basis" curriculum "classification+grading" based on seriously summing up the hierarchical teaching experience before, and made specific regulations from the testing and grading of the students, the students divided into classes, the record and evaluation of the students' achievements. They could be taken as the documents of implementation of "computer foundation" "classification+grading" teaching guidance.

Since the teaching task assigning and the arrangement of curriculum schedule were completed in last semester, at the arrangement of the original schedule, we had considered the teaching problems of" classification + grading", specially identified the timetabling principles of the public computer course. According to the equipments of school's public computer laboratory, the various types of students were arranged as several course arranging rows, one course arranging row had class at the same time. For example, students of every major in institute of physical education were arranged as one course arranging row and had classes at the same time of every week.

According to the "teaching implementation plan" above, at the beginning of the curriculum each semester, the school educational administration office issued a notice, which we the secondary college implemented and organized specifically, to test the students who opened the "computer basis" course this semester, in accordance with the requirements of the "computer basis" course examination with the purchased computer exam system. The main contents of the test are the basic knowledge of computer, computer operation and writing input, the daily use of office software (including Word, Excel, PowerPoint), basic knowledge of computer network and so on.

After the results of the test coming out, we classified the students according to the test results, combined with the amount of laboratory equipment sets. The students whose test scores reached 60 points or more, after we published scores and lists, could voluntarily apply (to confirm by signature), and achieved the exemption eligibility of "computer basis" course after the approval of the office of teaching affairs. They directly accessed to credits for this course, and the test score was the course achievement. For the students whose test scores were below 60 points, we collected and ordered the students in the same course arranging row according to the scores of the test. In accordance with provisions of the test scores in the "teaching implementation program" above, the students can be divided into high, middle and junior level. Teaching classes could be divided reasonably according to the amount of the laboratory equipment sets, and then we arranged the schedule after grading. Under normal circumstances, the same group (for example, a course arranging row contained 5 natural classes on Monday morning), would be arranged into a senior class, two intermediate classes and two junior classes.

The setting of teaching contents. On the classification of teaching contents, we organized the teachers to write the curriculum teaching program of three categories on the basis of extensive investigation. On the whole, for the students of class A and B, we basically follow the "teaching implementation scheme of computer basic core curriculum in colleges and universities " that the teaching steering commission put forward to sett up teaching contents. For the students of class C, in addition to set the basic contents of teaching in accordance with the students of class $\mathrm{B}$, we jointly carry out teaching and research activities with the corresponding professional teachers, discuss how to combine the personality characteristics of the students in music, physical education and fine arts majors and subsequent professional course learning needs to set the corresponding professional teaching module. For example, the students from different majors of the physical education institute, we take the organization of sports games and basketball games of an unit as an example, in the text 
processing section of teaching of office software, we set up the arranging skills of order books in sports competition, production skills of common forms in the competition process, the sketch map of sports venues and so on, and then organize the students to experiment and practice. In the part of electronic form, we increase the teaching and practice of automatic processing and statistical summary of sports competition performance, score, ranking and so on. In the part of the presentation production, we add the teaching and practice of the production skill of the sports competition propaganda poster, the drawing of the sketch map of technical action of athletes and so on.

In the process of grading teaching contents, we have carried on the targeted treatment according to the various kinds of teaching plan before. Since the foundation of the students of the senior class of different classification is weak, the teaching is organized by the conventional contents and teaching methods in the course of teaching and learning in the teaching of "The teaching implementation scheme of computer basic core curriculum in colleges and universities", which is proposed by the teaching steering commission. That is, the three categories of curriculum teaching plans proposed before can be used as the curriculum teaching plan of the primary courses of different categories. For the middle classes of different categories, these students have basically mastered the basic operation , we appropriately "increase or decrease" the teaching program of the corresponding primary class , that is, reducing the basic operational teaching contents, increasing principle of the teaching contents and skills of operation to form of the teaching program of the various middle classes.

Before implementing the specific teaching each semester, according to all kinds of high, middle and primary "computer basis" curriculum teaching implementation plans that written previously, through the collective teaching activities, we formulate different teaching schedule tables of high, middle and junior classes of different categories (including theoretical and experimental teaching schedule). The teachers are divided into three groups which are high, middle and junior classes to prepare lessons collectively, and form unified multimedia teaching courseware of different classes for the reference of the teachers. In the process of teaching. According to the actual situation of the students, the teachers then make the appropriate changes to the teaching courseware.

Dealing with the problems in the teaching process of “classification + grading". In the teaching process of "classification + classification", we must first determine the schedule to grading. The schedule contains laboratories and teachers of all the classes. As mentioned in the preceding, we arrange various of students as numbers of course groups, one group has classes at the same time. After determining the exemption students at the end of the test, the remaining students in the same group will be divided into three groups which refer to the high , middle and junior classes in accordance with the provisions of the "teaching implementation program" on score test. Then, according to the amounts of devices in the public computer labs, we will properly arrange the teaching classes study in which lab ( The number of students in the class can not exceed the number of lab computers, taking into account the uncertainty of equipment failure, keep some spare equipments. Due to the change of the amounts of students in all the classes, the teachers have to be made proper adjustments. We determine the new teachers of the classes according to the class and grade of the curriculum teaching plan the teacher writes. So, we had rearranged the grading schedule.

The second problem in the teaching of "classification and grading" to solve is the students' school management. After rearranging the actual classes of the students, the students will have classes in accordance with the new schedule. The new class regroups by the break up of the original natural classes through dividing the professions, the students list the teachers use in class, generally includes students of various professions. To improve the management of students, we select a student cadre as the person in charge in the various classes of students of every profession, who is responsible for contacting with the teachers, counting and reporting the students who is absent or asks for leave, and matters related to curriculum teaching. Since graded teaching is conducted, there is on concept of natural classes, department of students' management can not directly inspect the attendance rate of students class, which will lead to a decline in attendance rate of students. On this issue, on the one hand, teachers should be strict management, each class to the students' experimental records the sign and the experimental process and on the student attendance check and inform. On the one hand, teachers must strictly manage the students, take advantages of the students' experimental registration 
and the process of the experiment to check and report the attendance of students timely. On the other hand, teachers should strengthen the work of propaganda and education, clearly tell the students, according to the course assessment program, impacts of the situation in class on the achievement of course completion is great, and that in the process of teaching, especially the first few classes, guide the students to take the initiative to pay attention to the course learning by preaching to the students the status and roles this course plays in the whole system of professional talent.

In the teaching of "classification and classification", the last problem is the record of students' achievement and system logging, which is the most complex. Since the teaching tasks the school issues arrange the teachers taking natural class as a unit. In the school educational administration management system, the record of students' grades takes the class in the task book as a unit. According to the principle of the course teaching program of "computer basis" refers to the formation of the course grades and performance evaluation. The performance of the students of this course consists of usual scores (10\%), experimental scores (40\%) and the final assessment results (50\%). To ensure the correctness of the students' course performance, we first take the graded classes as the units of performance record and accounting of this course.

\section{The experience and feel of computer basic teaching of "classification + grading" in our university}

In nearly two years of "classification + grading” teaching practice, full consideration should be given to the diversity of students in local comprehensive university, the popularization of information technology in junior school, and the differences of the students' knowledge starting point caused by regional differences and differences between urban and rural areas. When classified teaching method is adopted, we can take full account of the different needs of computer operation skills and information technology for the students of different types of professions to mobilize the students' enthusiasm for learning; When the graded teaching method is adopted, the teachers are convenient for targeted teaching, and the students at all levels can get the corresponding information literacy training as well, which is in accordance with the students' aptitude. Exemption policy formulation is direct embodiment of the credit system teaching management, and also make few students liberated to have more time to study other professional knowledge; The re-combination classes made of the students from various professions further promote the exchange and integration of students from different professions.

Of course, the implementation of teaching of "computer basis" "classification + grading", is more of the reform of the organization in teaching. In order to improve the teaching quality of the "computer foundation" course, more attention must be paid to the reform and use of teaching methods and teaching means, and the construction and utilization of network teaching resources. The teaching modes such as MOOC/SPOC and flipped class can be well used in "computer basis" course teaching, and achieved good effects. This will be the main direction of the reform of public computer teaching in our school.

\section{Acknowledgments}

This paper is a provincial teaching research project of universities in Hubei Province in 2014 (higher education document[2015]1 issued by the education department of Hubei Province). Project name: Research and practice on the teaching of public computer course "classification +grading" in local comprehensive universities. Project number: 2014370.

\section{References}

[1] The steering committee of the teaching of computer basic courses in the higher education department of the Ministry of Education. Teaching implementation scheme of computer basic core curriculum in colleges and universities. Beijing. Higher Education Press. 2011.10 
[2] Hongjian Ren. Feasibility study on the graded teaching of computer information technology course in universities. Computer knowledge and technology. 2012.13

[3]Yongjie Li, Xiao Lv. Discussion on the optimization of the process of the graded teaching of computer basic course in universities. Contemporary education theory and practice. 2013.01

[4]Ye Tian, Wenbin Yang. On the reform of computer basic course in universities from the perspective of network survey. Journal of Taiyuan Normal University (social science edition), 2013.02

[5]Hongxi Jiang, etc. The organization and implementation of computer basic course in local comprehensive universities. Contemporary education practice and teaching resaearch.2014.11 